K A N D A I

\begin{tabular}{|l|l|r|}
\hline Volume 15 & No. 1, Mei 2019 & Halaman 75-86 \\
\hline
\end{tabular}

\title{
IKLAN TOKOBAGUS.COM: \\ ANALISIS STRUKTUR WACANA MODEL VAN DIJK (Tokobagus.com Advertisement: Van Dijk Model of Discourse Structure Analysis)
}

\author{
Lusi Widia Ardianto \& Syahrul Ramadhan \\ Fakultas Bahasa dan Seni, Universitas Negeri Padang \\ Jalan Prof. Dr. Hamka, Air Tawar, Padang, Indonesia \\ Pos-el: lusiwidia95@gmail.com
}

(Diterima 21 November 2018; Direvisi 10 Mei 2019; Disetujui 13 Mei 2019)

\begin{abstract}
In the current millennial era, people need an advertisement either through electronic or printed media. One of the advertisement that is loved by the people of Indonesia is online buying and selling shop. The purpose of this study is to describe and examine the structure of the Tokobagus.com advertisements by using the Van Dijk model structure. The type of this research is qualitative research. The data analysis technique is done qualitatively. The object of this research is Tokobagus.com advertisement. The analysis results show three points. First, superstructure consists of the headline, illustration, body copy, and signature lines. Second, microstructure consists of verbal elements and nonverbal elements. Third, the macrostructure, there are elements of the meaning of advertising and advertising messages. The discourse structure of the advertisement for Tokobagus.com store has used a complete structure of advertising discourse, so that it can emulate it to market a product or service and be able to attract buyers to buy the product or service offered.

Keywords: tokobagus.com advertisement, discourse, structure analysis, Van Dijk
\end{abstract}

Abstrak

Pada era milenial saat ini masyarakat membutuhkan suatu iklan baik melalui media elektronik maupun cetak. Salah satu iklan yang digandrungi masyarakat Indonesia adalah toko jasa jual beli online. Tujuan penelitian ini adalah mendeskripsikan dan menelaah struktur iklan "tokobagus.com" menggunakan struktur model Van Dijk. Jenis penelitian ini adalah penelitian kualitatif. Teknik analisis data dilakukan secara kualitatif. Objek penelitian ini adalah iklan "tokobagus.com". Hasil penelitian menunjukkan bahwa, pertama, superstruktur, yang terdiri atas struktur headline (kepala iklan), illustration (ilustrasi), body copy (isi iklan), dan signature line (logo). Kedua, struktur mikro, yang terdiri atas unsur verbal dan unsur nonverbal. Ketiga, struktur makro, yang terdapat unsur makna iklan dan pesan iklan. Struktur wacana iklan tokobagus.com telah menggunakan struktur wacana iklan yang lengkap, sehingga pembaca dapat menirunya untuk memasarkan produk atau jasa dan mampu menarik minat pembeli untuk membeli produk atau jasa yang ditawarkan.

Kata-kata kunci: iklan tokobagus.com, wacana, analisis struktur, Van Dijk

DOI: $10.26499 / j k . v 15 i 1.1003$

How to cite: Ardianto, L.W., \& Ramadhan, S. (2019). Iklan tokobagus.com: Analisis struktur wacana model Van Dijk. Kandai, 15(1), 75-86 (DOI:10.26499/jk.v15i1.1003) 


\section{PENDAHULUAN}

Media iklan terbagi menjadi dua jenis, yakni elektronik dan cetak. Media iklan merupakan sarana yang digunakan untuk memberikan informasi kepada masyarakat yang memerlukannya. Pada era milenial ini banyak iklan tidak dapat dimaknai secara langsung oleh masyarakat.

Wacana dalam iklan adalah substansi ideologis yang tersembunyi dalam struktur teks, baik yang bersifat verbal maupun visual. Secara ideologi iklan memang sebuah wacana yang mewacanakan berbagai aspek kehidupan dalam masyarakat dan memang diperlukan masyarakat. Iklan menjadi instrumen dalam sistem kemasyarakatan (ekonomi, sosial, politik, dan budaya), maka keberadaan iklan tidak terlepas dari konteks sistem yang meliputinya. Iklan sebagai sebuah teks sosial bisa digunakan untuk memahami dinamika masyarakat selama periode ketika iklan tersebut dimunculkan, dan juga mampu merespon perkembangan-perkembangan kunci yang terjadi dalam sebuah sistem sosial dimana iklan tersebut menjadi salah satu bagian dari sistem tersebut (Setianto, 2015).

Dalam sebuah iklan, di samping esploitasi bahasa, tampilan unsur nonkebahasaan (nonverbal) juga menjadi bagian penting. Unsur ini dimanfaatkan untuk menyampaikan pesan mengenai produk yang ditawarkan. Masyarakat harus jeli melihat apa yang ingin disampaikan oleh pihak produsen melalui penanda verbal dan nonverbal dalam iklan tersebut.

Penelitian tentang analisis wacana iklan telah dilakukan oleh Musaffak (2015) yang mengkaji tentang iklan makanan dan minuman di televisi; Nirmala (2015) mengkaji tentang tindak tutur ilokusi pada iklan komersial Sumatera Ekspres; Ahmadi dan
Mahardika (2016) mengkaji tentang kohesi dan koherensi pada wacana iklan politik; Nisa (2016) mengkaji tentang iklan radio Gema FM Banjarmasin; Setiyono dan Sutrimah (2016) mengenai iklan operator seluler; Tenggono dan Sulistyarini (2016) mengkaji tentang pesan moral pada iklan rokok Sampoerna; Fitriani (2019); mengkaji tentang tindak tutur wacana iklan radio; Wicaksono (2019) mengkaji tentang analisis wacana iklan operator seluler. Berdasarkan analisis dalam penelitianpenelitian tersebut, diketahui bahwa iklan dapat ditampilkan dengan berbagai bentuk dan tampilan yang kreatif, abstraktif, dan tentunya persuasif.

Leech (1966) menyatakan bahwa secara umum iklan terdiri atas lima struktur pembentuk yaitu headline (kepala iklan), illustrations (ilustrasi), body copy (isi iklan), signature line (logo), dan standing details (penutup). Bagian struktur yang dibagi oleh Leech merupakan bagian dari struktur superstruktur menurut Van Dijk.

Dalam penelitian ini, iklan dianalisis berdasarkan kerangka analisis wacana yang dicetuskan oleh Van Dijk. Kerangka ini terdiri atas tiga struktur utama, yaitu struktur makro, superstruktur, dan struktur mikro (Eriyanto, 2001).

Sebelumnya, penelitian dengan menerapkan analisis wacana kritis model Van Dijk ini telah banyak dilakukan, di antaranya Imam (2012) mengenai lirik lagu; Karman (2014) mengenai wacana anti politik barat pada media; Indrayana (2014) meneliti tentang iklan produk frestea di televisi; Setianto (2015) mengenai iklan politik; Indiastini (2016) meneliti iklan lowongan pekerjaan; Hartini (2017) tentang meme gamers; dan Lado (2014); Suciartini (2017); serta Payuyasa (2017) meneliti tentang wacana dalam program mata Najwa di televisi. Hasil analisis dari penelitian- 
penelitian tersebut pada umumnya menunjukkan bahwa analisis model Van Dijk dapat dimanfaatkan untuk menganalisis wacana kritis pada struktur teks dan wacana.

Dari penelitian terkait, dapat dilihat bahwa analisis model Van Dijk ini bisa dilakukan dalam penelitian dengan jenis wacana beragam. Dalam penelitian ini pembahasan difokuskan pada iklan. Salah satu iklan yang banyak digunakan masyarakat di era milenial saat ini adalah iklan toko jasa jual beli online. Alasan memilih iklan toko jasa jual beli online sebagai objek penelitian adalah karena di era milenial saat ini masyarakat banyak beralih ke dunia digital di mana semua hal terasa berada dalam satu genggaman, yakni media sosial. Toko jasa jual beli online merupakan solusi bagi masyarakat yang tidak memiliki waktu untuk berbelanja ke toko secara langsung.

Indonesia memiliki banyak pilihan toko jasa jual beli online, salah satunya adalah Tokobagus.com. Tokobagus.com sebagai salah satu media berbelanja secara online cukup diminati oleh masyarakat. Sebagai sebuah produk, Tokobagus.com pun perlu sosialisasi berupa iklan. Dari segi pemasaran 'marketing' pengiklanan Tokobagus.com mudah dipahami dan menarik sehingga penyampaian pesan dan makna terkait situs jual-beli ini yang ingin disampaikan kepada konsumen memberikan stimulasi bagi calon konsumen.

Iklan Tokobagus.com dengan tampilan yang dapat dijumpai baik di media cetak, elektronik, maupun digital mengundang masyarakat untuk menjadi penggunanya. Aspek-aspek yang terkandung di dalam iklan ini secara utuh memang dimaksudkan untuk menarik konsumen. Berangkat dari sini, dipandang perlu untuk mengkaji wacana yang ada dalam iklan situs toko jual-beli online ini. permasalahan yang menjadi fokus penelitian adalah, bagaimana wacana iklan Tokobagus.com berdasarkan analisis struktur model Van Dijk? Penelitian ini bertujuan mendeskripsikan wacana iklan Tokobagus.com berdasarkan analisis struktur model Van Dijk.

\section{LANDASAN TEORI}

\section{Iklan sebagai Teks dan Wacana}

Iklan merupakan alat atau sarana untuk menarik perhatian seseorang terhadap sesuatu atau menginformasikan sesuatu kepada seseorang. Iklan disebut sebagai sebuah teks pada saat iklan dipandang sebagai hasil produksi (produk). Produsennya adalah pencipta iklan. Pada saat ini iklan tidak lebih dari sebuah bentuk kreasi perpaduan tanda (semiotik) murni, terlepas dari fungsi sosialnya sebagai sebuah media komunikasi dan pemasaran. Sementara, iklan disebut sebagai wacana ketika iklan dipandang sebagai sebuah bentuk media komunikasi dan pemasaran produk barang atau jasa. Pada saat ini iklan tidak lagi dipandang sabagai perpaduan tanda (semiotik) semata namun juga dipandang sebagai sebuah bentuk komunikasi yang melibatkan aspek kontekstual di luar unsur tekstual pembentuknya (Dyer, 1982).

Sulastri (2017) menyatakan iklan dimaknai sebagai berita pesanan untuk mendorong, membujuk khalayak ramai agar tertarik pada barang dan jasa yang ditawarkan, serta pemberitahuan kepada khalayak mengenai barang dan jasa yang dijual, dipasang di dalam media massa (seperti surat kabar dan majalah) atau tempat umum. Berdasarkan definisi tersebut jelaslah bahwa iklan pada dasarnya adalah sesuatu yang diberitahukan atau hal pemberitahuan. Selanjutnya, Indiastini (2016) 
mengemukakan bahwa iklan itu juga disuguhkan, ditawarkan, dan dijual.

\section{Analisis Struktur Wacana Model Van Dijk}

Melalui berbagai karyanya, Van Dijk mencetuskan kerangka analisis wacana yang terdiri atas tiga struktur utama, yaitu struktur makro, superstruktur, dan struktur mikro (Eriyanto, 2001).

\section{Struktur Makro}

Struktur makro merupakan makna global/umum dari sebuah teks yang dapat dipahami dengan melihat topik dari sebuah teks. Dengan kata lain, analisis struktur makro merupakan analisis sebuah teks yang dipadukan dengan kondisi sosial di sekitarnya untuk memperoleh satu tema sentral. Tema sebuah teks tidaklah terlihat secara eksplisit di dalam teks, melainkan tercakup di dalam keseluruhan teks secara satu kesatuan bentuk yang koheren. Jadi, tema sebuah teks dapat ditemukan dengan cara membaca teks tersebut secara keseluruhan sebagai sebuah wacana sosial sehingga dapat ditarik satu ide pokok atau topik atau gagasan yang dikembangkan dalam teks tersebut (Eriyanto, 2001; Imam, 2012).

\section{Superstruktur}

Superstruktur merupakan kerangka dasar sebuah teks yang meliputi susunan atau rangkaian struktur atau elemen sebuah teks dalam membentuk satu kesatuan bentuk yang koheren. Dengan kata lain, analisis superstruktur merupakan analisis skema atau alur sebuah teks. Seperti halnya sebuah bangunan, sebuah teks juga tersusun atas berbagai elemen, seperti pendahuluan, isi, dan penutup, yang harus dirangkai sedemikian rupa, guna membentuk sebuah teks yang utuh dan menarik.
Dalam sebuah iklan, superstruktur merupakan struktur pembentuk iklan yang meliputi kepala iklan 'headline', ilustrasi 'illustrations', isi iklan 'body copy', logo 'signature line', dan penutup 'standing details' (Eriyanto, 2001; Imam, 2012).

\section{Struktur Mikro}

Struktur mikro merupakan analisis sebuah teks berdasarkan unsur-unsur intrinsiknya. Unsur intrinsik struktur mikro terbagi menjadi unsur-unsur berikut.

(a) Unsur semantik yang dalam hal ini dikategorikan sebagai makna lokal (local meaning), yakni makna yang muncul dari kata, klausa, kalimat, dan paragraf, serta hubungan di antara mereka, seperti hubungan antarkata, antarklausa, antarkalimat, dan antarparangraf yang membangun satu kesatuan makna dalam satu kesatuan teks.

(b) Unsur sintaksis merupakan satu elemen yang membantu pembuat teks memanipulasi keadaan dengan cara memberikan penekanan secara tematik pada tatanan kalimat. Manipulasi tersebut dapat berupa pemilihan penggunaan kata, kata ganti, preposisi, dan konjungsi, serta pemilihan bentuk-bentuk kalimat seperti kalimat pasif atau aktif.

(c) Unsur stilistik merupakan unsur style atau ragam tampilan sebuah teks dengan menggunakan bahasa sebagai sarananya. Sebuah teks bisa memilih berbagai ragam tampilan seperti puisi, drama, atau narasi. Terkait gaya bahasanya, sebuah teks bisa menampilkan style melalui diksi/pillihan kata, pilihan kalimat, majas, matra, atau ciri kebahasaan yang lainnya.

(d) Unsur retoris merupakan unsur gaya penekanan sebuah topik dalam sebuah teks. Gaya penekanan ini 
berhubungan erat dengan bagaimana pesan sebuah teks akan disampaikan, yang meliputi gaya hiperbola, repetisi, aliterasi atau gaya yang lainnya.

(Eriyanto, 2001; Imam, 2012).

\section{METODE PENELITIAN}

Objek penelitian adalah wacana dalam iklan Tokobagus.com. Teknik analisis data dilakukan secara kualitatif karena data yang diteliti adalah data yang tidak dapat diukur secara langsung. Penelitian kualitatif mengedepankan analisis induktif dengan menghadirkan uraian, diikuti dengan uraian pemaknaan. Selanjutnya, pembahasan mengerucut dan mengkristal pada perumusan singkat, padat, dan simpulan (Yin, 2005).

\section{PEMBAHASAN}

Iklan Tokobagus.com dapat dijumpai dalam berbagai media, baik cetak, elektronik, maupun media digital. Iklan Tokobagus.com dikemas dan ditampilkan melalui sebuah logo dan slogan sebagaimana dapat dilihat pada Gambar 1 berikut.

Gambar 1

Wacana Iklan Toko Jasa Jual Beli Online

\section{tokobagus}

Jual Beli Bagus!

Selanjutnya, pembahasan dan analisis secara menyeluruh mengacu pada iklan dalam Gambar 1 sebagai data, yang diposisikan sebagai sebuah wacana.

\section{Struktur Wacana Iklan}

Berikut ini adalah satu contoh aplikasi analisis wacana berdasarkan struktur pembentuknya sesuai dengan yang dicetuskan oleh Van Dijk. Toko jasa jual beli online yang diiklankan bernama Tokobagus.com. Di dalam iklan ini termuat slogan "Tokobagus.com, Jual Beli Bagus!" sebagaimana terlihat dalam Gambar 1. Dari tampilan iklan ini tampak bahwa pihak pengiklan ingin menyampaikan bahwa toko jasa jual beli online, pada situs tersebut bagus untuk digunakan dan merupakan solusi bagus untuk menjual barang maupun membeli barang secara online, tentunya digunakan/dilakukan oleh orang yang bagus. Berikut ini adalah analisis selengkapnya.

\section{Superstruktur}

Analisis superstruktur sebuah wacana merupakan suatu analisis yang lebih cenderung berupa indentifikasi struktur pembentuk wacana. Situs toko jasa jual beli online Tokobagus.com terdiri atas empat struktur pembentuk iklan sebagaimana dicetuskan Leech, yaitu headline (kepala iklan), illustration (ilustrasi), body copy (isi iklan), dan signature line (logo). Pada iklan ini (lihat Gambar 1) ikon situs toko jasa jual beli online yang diiklankan juga berperan sebagai latar belakang. Jadi selain sebagai signature line (logo), ikon situs toko jual beli online iklan ini juga berperan sebagai latar belakang.

\section{Struktur Headline (Kepala Iklan) \\ Headline iklan Tokobagus.com secara padu hadir dalam tampilan iklan. Ikon gambar lampu yang bercahaya, ditandai dengan adanya tiga garis di atasnya, menjadi headline iklan ini. Berikut gambar headline yang dimaksud.}


Gambar 2

Wacana Iklan Toko Jasa Jual Beli Online

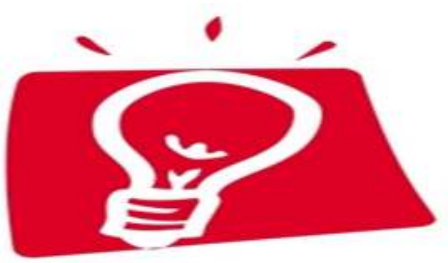

Gambar lampu bercahaya merupakan simbol pencahayaan bagi orang yang berpikir dan merupakan sebagai pernyataan bahwa orang bagus atau pintar, tentu akan berpikir untuk menggunakan situs toko jual beli online yang bagus, dan Tokobagus.com merupakan solusinya.

\section{Struktur Illustration (Ilustrasi)}

Struktur illustration (ilustrasi) pada iklan ini terdiri atas 3 komponen warna, yaitu putih, hitam, dan merah. (1) Warna putih melambangkan kemurnian, kesederhanaan, tidak bersalah, dan minimalisme. Jika dilakukan identifikasi suatu merek yang menggunakan warna putih untuk penyampaian pesan mengharapkan sesuatu terbaca dari pemilihan warna ini. Warna putih dapat merepresentasikan kederhanaan, keabsolutan, dan kesterilan dari jasa/produk mereka secara bentuk dan fungsi. (2) Warna hitam melambangkan canggih, formal, dan mewah. Warna hitam biasanya digunakan untuk pengenalan merek karena merupakan warna khusus, mudah diingat, dan komunikatif sebagai atribut merek. Selanjutnya, (3) warna merah berfungsi sebagai menyatakan gairah, kegembiraan, keberanian, energi, kekuatan, dan kepercayaan diri. Warna merah memiliki asosiasi kontekstual dalam menyampaikan merek yang berbeda dan di dalam branding dapat menyampaikan pesan yang terlihat (https://www.canva.com).

Struktur Body Copy (Isi Iklan)
Struktur body copy (isi iklan) terdiri atas unsur verbal dan unsur nonverbal. Unsur verbal merupakan komunikasi secara verbal yang pesannya disampaikan dalam bentuk lisan maupun tulisan, sedangkan unsur nonverbal adalah model komunikasi secara nonverbal yang melibatkan fasilitas nonverbal sebagai media penyampai pesan.

\section{1) Unsur Verbal}

Dalam unsur verbal digunakanlah kata-kata sebagai media penyampaiannya, baik secara lisan maupun tulisan. Ada beberapa unsur penting dalam komunikasi verbal, yaitu melalui bahasa dan kata-kata. Berikut ini unsur verbal dalam iklan Tokobagus.com.

a) Tokobagus.com

Kata Tokobagus.com secara lugas menunjukkan bahwa kata ini merujuk pada sebuah situs. Adanya “.com" di belakang kata menguatkan perujukan ini. Perusahaan iklan tersebut ingin menyampaikan eksistensi sebuah toko online yang bagus untuk berjual beli.

b) Jual beli bagus!

Kalimat "Jual beli bagus!" tersebut menyatakan bahwa toko online ini bagus. Transaksi yang dilakukan dalam toko online ini dijamin berkualitas bagus. Bahkan diberi penekanan dengan hadirnya tanda seru (!) yang dapat diartikan sebagai perintah untuk menggunakannya.

2) Unsur Nonverbal

Unsur nonverbal merupakan komunikasi secara nonverbal, sebagai media penyampaiannya digunakan pesan yang dikemas dalam bentuk nonverbal, yaitu tanpa kata-kata. Ada beberapa unsur penting dalam komunikasi nonverbal. Sebagai media penyampaiannya dapat menggunakan 
bahasa tubuh, tanda atau lambang, tindakan atau perbuatan, dan objek. Berikut ini unsur nonverbal dalam iklan tokobagus.com.

a) Gambar lampu

Ikon gambar lampu yang bercahaya ditandai dengan adanya tiga garis di atas gambar lampu tersebut. Gambar lampu bercahaya merupakan simbol pencahayaan bagi orang yang berpikir dan merupakan sebagai pernyataan bahwa orang bagus atau pintar, tentu akan berpikir untuk menggunakan situs toko jual beli online yang bagus, dan "tokobagus.com" merupakan solusinya.

b) Warna

Terdapat tiga komponen warna, yaitu putih, hitam, dan merah. Masingmasing warna memiliki penafsiran yang berbeda-beda karena secara umum warna membawa fungsi sebagai simbol untuk keadaan tertentu. Warna putih berfungsi sebagai perlambang kemurnian, kesederhanaan, tidak bersalah, dan minimalisme. Jadi, dalam sebuah merek, warna putih diidentifikasi sebagai alat untuk menyampaikan representasi kederhanaan, keabsolutan, dan kesterilan dari jasa/produk yang ditawarkan secara bentuk dan fungsi. Warna hitam berfungsi untuk melambangkan sifat canggih, formal, dan mewah. Warna hitam biasanya digunakan untuk penggenalan merek karena merupakan warna yang khusus, mudah diingat, dan komunikatif sebagai atribut merek. Selanjutnya, warna merah berfungsi sebagai simbol untuk menyatakan gairah, kegembiraan, keberanian, energi, kekuatan, dan kepercayaan diri. Warna merah memiliki asosiasi kontekstual dalam menyampaikan merek yang berbeda dan di dalam branding berfungsi untuk menyampaikan suatu pesan yang ingin disampaikan oleh pihak pengiklan kepada konsumen. (https://www.canva.com).

\section{Struktur Signature Line (Logo)}

Struktur signature line (logo) pada iklan "tokobagus.com" ini terdiri atas dua bagian, yaitu ikon produk toko jasa jual beli online yang diiklankan dan slogan produk. Setelah disampaikan pada awal analisis di atas, ikon produk "tokobagus.com" sebagai latarbelakang. Sedangkan slogan produk terletak pada bagian bawah, yaitu "jual beli bagus!".

\section{Struktur Mikro}

Analisis struktur mikro adalah analisis struktur wacana secara tekstual. Analisis tekstual ini meliputi analisis unsur verbal dan nonverbal. Berikut ini analisis struktur atas unsur verbal dan nonverbal iklan Tokobagus.com.

\section{Unsur Verbal}

Pada iklan toko jasa jual beli online ini, unsur verbal terdapat pada bagian body copy (kepala iklan) dan signature line (logo). Signature line (logo) iklan ini berupa slogan "Jual Beli Bagus!". Sementara itu, body copy (isi iklan) merupakan penjelasan tentang produk/jasa yang diiklankan, yakni sebuah media jual-beli online yang diberi nama"Tokobagus.com".

Pada tatanan leksikal, iklan "tokobagus.com" ini menunjukkan adanya proses pengulangan. Proses ini terjadi pada kata "bagus". Proses pengulangan terjadi pada kalimat pertama dan kalimat kedua. Proses pengulangan pada kedua kata ini dilakukan sebagai bentuk penegasan akan pentingnya kata "bagus" tersebut.

\section{Unsur Nonverbal}

Unsur nonverbal iklan terdapat pada headline (kepala iklan) dan 
illustrasion (ilustrasi). Headline (kepala iklan) ini adalah ikon gambar lampu yang bercahaya ditandai dengan adanya tiga garis di atas gambar lampu tersebut. Gambar lampu bercahaya merupakan simbol pencahayaan bagi orang yang berpikir dan merupakan sebagai pernyataan bahwa orang bagus atau pintar, tentu akan berpikir untuk menggunakan situs toko jual beli online yang bagus, dan "tokobagus.com" merupakan solusinya.

Dari Gambar 1 terlihat bahwa pada iklan ini illustration (ilustrasi) terdiri atas tiga unsur warna, yaitu putih, hitam, dan merah. Warna putih dapat diartikan sebagai lambang kemurnian, kesederhanaan, tidak bersalah, dan minimalisme. Jika kita mengidentifikasi suatu merek yang menggunakan warna putih, untuk menyampaikan pesan merek maka warna putih mereprentasikan kederhanaan, keabsolutan, dan kesterilan dari jasa/produk mereka secara bentuk dan fungsi. Warna hitam di sini berfungsi untuk melambangkan canggih, formal, dan mewah. Warna hitam biasanya digunakan untuk penggenalan merek karena merupakan warna khusus, mudah diingat, dan komunikatif sebagai atribut merek. Selanjutnya, warna merah berfungsi sebagai simbol menyatakan gairah, kegembiraan, keberanian, energi, kekuatan, dan kepercayaan diri. Warna merah memiliki asosiasi kontekstual dalam menyampaikan merek yang berbeda dan di dalam branding dapat menyampaikan suatu pesan yang ingin disampaikan oleh pihak pengiklan.

Dalam iklan Tokobagus.com, warna merah dan putih pada gambar lampu mengemban makna perlambangan. Warna putih untuk menyampaikan sebagai ide/pemikiran yang murni dan warna merah merupakan perlambang bahwa ide atau pemikiran tersebut didapatkan melalui tindakan berani untuk mengambil resiko. Seseorang untuk maju perlu melakukan keberanian dalam dirinya. Kata "bagus" dan ".com" sengaja diberi hitam biar terkesan formal, canggih, mudah diingat, dan komunikatif.

Frasa "Jual Beli Bagus!" dilatarbelakangi dengan dua warna, yakni putih dan merah. Warna putih pada frasa "Jual Beli Bagus!" dapat menyampaikan pesan sebagai ide/pemikiran yang murni untuk memulai jual beli online secara bagus. Selanjutnya, warna merah merupakan ide/pemikiran tersebut didapatkan melalui tindakan berani untuk mengambil risiko. Tindakan berani seperti ini diperlukan untuk memperoleh kemajuan.

\section{Analisis Struktur Makro}

Pada tahap analisis struktur makro ini, analisis dibagi menjadi dua bagian, yaitu analisis makna dan analisis pesan iklan. Analisis dilakukan melalui pendekatan kontekstual dengan didukung oleh analisis struktur mikro sebelumnya. Berikut analisis struktur makro iklan Tokobagus.com yang mempertimbangkan aspek makna dan pesan yang tersampaikan melalui iklan ini.

\section{Makna Iklan}

Makna iklan pada wacana iklan Tokobagus.com ini difokuskan pada headline (kepala iklan) dan illustration (ilustrasi). Makna iklan dipertegas oleh unsur verbal yang terdapat pada body copy (isi iklan) dan signature line (logo). Jadi, unsur verbal berfungsi sebagai sebuah bentuk penegasan untuk mendukung makna pada headline dan ilustration. Sesuai dengan acuan analisis yang ada, analisis teks yang ada dalam iklan dipadukan pemaknaannya dengan 
aspek kontekstual yang melingkupi iklan tersebut.

Pada headline (kepala iklan), ikon gambar lampu bercahaya, yang ditandai dengan adanya tiga garis di atas gambar lampu tersebut, mengandung makna tertentu. makna yang diharapkan tentunya selaras dengan misi pembuat iklan dalam mencitrakan produknya. Gambar lampu bercahaya merupakan simbol pencahayaan bagi orang yang berpikir dan merupakan sebagai pernyataan, bahwa orang bagus atau pintar tentu akan berpikir untuk menggunakan situs toko jual beli online yang bagus, dan Tokobagus.com merupakan solusinya.

Berdasarkan penjelasan yang terdapat pada body copy (isi iklan), frasa Toko bagus.com, dengan merujuk pada adanya kata ".com", langsung diketahui bahwa yang dimaksud di sini berupa sebuah situs. Perusahaan iklan tersebut ingin menyampaikan adanya sebuah toko online yang bagus untuk jual dan beli barang. Selanjutnya, melalui frasa "Jual Beli Bagus!" pembuat iklan ingin menyatakan bahwa toko online ini memiliki spesifikasi sebagai media jual beli yang bagus, bahkan diberi penekanan dengan tanda seru (!) yang dapat diartikan sebagai perintah untuk menggunakannya.

Warna merah dan putih pada gambar lampu dapat bermakna warna putih untuk menyampaikan sebagai ide/pemikiran yang murni. Selanjutnya, warna merah merupakan ide/pemikiran tersebut didapatkan melalui tindakan berani untuk mengambil resiko. Seseorang untuk maju perlu melakukan keberanian dalam dirinya. Kata "bagus" dan ".com" sengaja diberi warna hitam agar terkesan formal, canggih, mudah diingat, dan komunikatif.

Frasa "Jual Beli Bagus!" sebagai slogan dilatarbelakangi dengan dua warna, yakni putih dan merah. Warna putih pada frasa "Jual Beli Bagus!" dapat menyampaikan makna adanya ide/pemikiran yang murni untuk memulai jual beli online secara bagus, dan warna merah merupakan ide/pemikiran tersebut didapatkan melalui tindakan berani untuk mengambil resiko. Seseorang untuk maju perlu melakukan keberanian dalam dirinya.

Berdasarkan kondisi tersebut dapat disimpulkan bahwa toko jasa jual beli online Tokobagus.com ini mampu memenuhi kebutuhan masyarakat. Diketahui bahwa pada era globalisasi masyarakat membutuhkan berbelanja secara online dengan gawai, tanpa harus keluar rumah atau kantor berpanaspanasan dan bermacet-macetan. Melalui gawai di tangan, calon konsumen dapat membeli dan menjual barang tanpa harus keluar ruangan.

\section{Pesan Iklan}

Sebagaimana telah diketahui bersama, analisis pesan wacana sebuah iklan merupakan analisis iklan seutuhnya atau secara satu kesatuan. Pada iklan Tokobagus.com ini pembuat iklan berupaya menunjukkan bahwa Tokobagus.com mengajak masyarakat beralih melakukan transaksi ke dunia digital. Tuntutan zaman membuat manusia mau tidak mau berada pada masa globalisasi, di mana dunia seolah berada dalam genggaman, yakni melalui media sosial. Tokobagus.com ingin memberi kenyamanan berupa jasa toko jual beli online yang merupakan solusi bagi masyarakat yang tidak memiliki waktu untuk ke toko secara langsung. Namun, dengan adanya Tokobagus.com calon konsumen dapat berbelanja di situs tersebut melalui gawainya tanpa harus berpanas-panasan keluar ruangan. Pilihan ini menunjukkan tindakan yang dinilai diinisiasi karena adanya kecerdasan berpikir dari sang calon 
konsumen. Berdasarkan hal tersebut dipilihlah gambar lampu bercahaya menjadi ikon yang dikedepankan dalam iklan Tokobagus.com.

Hasil analisis data menunjukkan bahwa penelitian ini memiliki persamaan dan perbedaan dengan penelitian Sulastri (2017). Persamaan terletak pada telaah wacana iklan dari segi struktur, sedangkan perbedaan terdapat pada analisis struktur, di sini Sulastri menggunakan teori struktur Baryadi (2002) terdiri atas tiga bagian, yakni bagian awal, bagian isi, dan bagian penutup, sedangkan dalam penelitian ini menggunakan teori struktur model Van Dijk yang terbagi tiga bagian, pertama, superstruktur, terdiri atas struktur headline (kepala iklan), illustration (ilustrasi), body copy (isi iklan), dan signature line (logo). Kedua, struktur mikro, terdiri atas unsur verbal dan unsur non-verbal. Ketiga, struktur makro, terdapat unsur makna iklan dan pesan iklan.

\section{PENUTUP}

Superstruktur wacana iklan Tokobagus.com, yakni headline (kepala iklan) berupa ikon gambar lampu bercahaya dan ditandai dengan adanya tiga garis diatas gambar lampu tersebut. Illustation (ilustrasi) ditandai dengan adanya tiga komponen warna, yakni putih, hitam, dan merah. Body copy (isi iklan), terdiri atas unsur verbal (frasa "Toko bagus.com" yang merujuk pada sebuah situs dan frasa "Jual Beli Bagus!" yang menyatakan bahwa toko online ini memiliki kualitas jual beli yang bagus. Kesan ini diberi penekanan tanda seru (!) sebagai perintah untuk menggunakannya) dan unsur nonverbal. Signature line (logo) pada iklan Tokobagus.com ini terdiri atas dua bagian, yaitu ikon produk toko jasa jual beli online dan slogan produk.
Struktur mikro wacana iklan Tokobagus.com terdiri atas unsur verbal dan nonverbal. Unsur verbal terdapat pada bagian body copy (isi iklan) dan signature line $(\operatorname{logo})$, sedangkan unsur nonverbal terdapat pada headline (kepala iklan) dan illustration (ilustrasi).

Struktur makro wacana iklan Tokobagus.com terdiri atas makna pesan. Makna iklan pada wacana iklan Tokobagus.com ini difokuskan pada headline (kepala iklan) dan illustrasion (ilustrasi). Makna pada headline (kepala iklan) dipertegas oleh unsur verbal pada body copy (isi iklan) dan signature line (logo). Pesan pada iklan Tokobagus.com terintegrasi dalam tampilan iklan ini seutuhnya, baik struktur makro maupun struktur mikro secara tekstual dan kontekstual.

Saran yang dapat diberikan dari hasil kajian dalam penelitian ini adalah struktur wacana iklan harus menggunakan struktur wacana iklan yang lengkap agar menarik minat pembeli untuk membeli produk atau jasa yang ditawarkan. Selanjutnya, iklan harus memiliki makna dan pesan yang ingin disampaikan baik itu secara tersurat maupun tersirat. Pesan dan makna yang disampaikan mampu mencerminkan karakter atau kekhasan dari perusahaan yang mengiklankan produk atau jasa.

\section{DAFTAR PUSTAKA}

Ahmadi, Y. F. \& Mahardika, R. Y. (2016). Analisis wacana kohesi dan koherensi pada wacana iklan politik dalam wacana pemilu 2014. Jurnal Ilmiah UPT P2M STKIP Siliwangi, 3(1), 19-24.

Baryadi, I.P. (2002). Dasar-dasar analisis wacana dalam ilmu bahasa. Yogyakarta: Pustaka Gondho Suli. 
Belajar arti wacana dan simbol. Diperoleh dari https://www.canva.com/id id/belajar/arti-warna-dan-simboldari-merk.

Dyer, G. (1982). Advertising as communication. London and New York: Routledge.

Eriyanto. (2001). Analisis wacana: pengantar analisis teks media. Yogyakarta: PT. LKIS Printing Cemerlang.

Fitriani, W.A.C. (2019). Analisis tindak tutur dalam wacana iklan radio. Jurnal Lingua Rima: Jurnal Pendidkan Bahasa dan Sastra Indonesia, 8(1), 51-59.

Hartini, S. (2017). Analisis wacana pada meme gamers Mario Teguh di facebook. Jurnal Online Kinesik, 4(2), 111-126.

Imam, A. F. (2012). Analisis wacana Van Dijk pada lirik lagu irgaa tani (My heart will go on)". Journal of Arabic Learning and Teaching. LAA 1(1), 1-8.

Indiastini, T. (2016). Wacana iklan lowongan pekerjaan di harian Kedaulatan Rakyat. Prosiding. Seminar Hasil Penelitian Kebahasaan dan Kesastraan., Yogyakarta: CV Azzagrafika.

Indrayana, A. (2014). Analisis wacana kritis komodifikasi budaya lokal pada iklan televisi: Studi kasus produk Frestea versi hiphop wedding. Jurnal DEKAVE, 7(2), $35-46$.

Karman. (2014). Dominasi wacana antipolitik barat pada media-muslim revivalis: Analisis wacana model Teun Van Dijk Tabloid Media Umat edisi pemilu 2014. Jurnal Studi Komunikasi dan Media, 18(2), 229-245.
Lado, C. R. (2014). Analisis wacana kritis program Mata Najwa "Balada Perda" di Metro TV. Jurnal E-Komunikasi, 2(2), 1-12.

Leech, G. N. (1966). English in advertising: A linguistic study of andvertising in Great Britain. London and New York: Longman.

Mussafak. (2015). Analisis wacana iklan Makanan dan minuman pada televisi berdasarkan struktur dan fungsi bahasa. Kembara, Jurnal Keilmuan Bahasa, Sastra, dan Pengajarannya, 1(2), 224-232.

Nirmala, V. (2015). Tindak tutur ilokusi pa da iklan komersial Sumatera Ekspres. Kandai 11(2), 139-150.

Nisa, F. (2016). Analisis wacana iklan radio Gema FM Banjarmasin. Jurnal Vidya Karya, 31(1), 3744.

Payuyasa, I. Y. (2017). Analisis wacana kritis model Van Dijk dalam program acara Mata Najwa di Metro TV. Segara Widya Jurnal Hasil Penelitian. Vol. 5, 14-24.

Setianto, W. A. (2015). Wacana dan representasi ideologi iklan politik di awal reformasi. Jurnal IptekCom, 17(2), 99-112.

Setiyono, J. \& Sutrimah. (2016). Analisis teks dan konteks pada iklan operator seluler (XL dengan kartu AS). Jurnal Pedagogia, 5(2), 297-310.

Suciartini, N. N. A. (2017). Analisis wacana kritis "semua karena Ahok" program Mata Najwa Metro TV. Jurnal Aksara, 29(2), 267-282. 
Sulastri, H. (2017). Telaah wacana iklan penjualan rumah dalam media massa cetak. Jurnal Pujangga, 3(1), 22-36.

Tenggono, C. M. \& Sulistyarini, D. (2016). Analisis semiotika pesan moral dalam iklan rokok Sampoerna a mild "go ahead" di media televisi. Prosiding. Prosiding Seminar Nasional Komunikasi 2016, 390-396.
Wicaksono, A. (2019). Analisis wacana kritis iklan operator seluler (teks dan konteks iklan XL dengan kartu AS). Jurnal Ksatra: Jurnal Kajian Bahasa dan Sastra, 1(1), 1-14.

Yin, R. K. (2005). Studi kasus: desain dan metode, penerjemah Mudzakir, M.D. Jakarta: Raja Grafindo Persada. 